\title{
ПРОБЛЕМА ВНУТРІШНЬОЇ ТА СОЩАЛЬНОЇ ІЗОЛЬОВАНОСТІ ОСОБИСТОСТІ У ТВОРЧОМУ ДОРОБКУ Б. Д. ГРІНЧЕНКА
}

Коломієць Н. Є., Яременко Н. В. Проблема внутрішньої та соціальної ізольованості особистості у творчому доробку Б. Д. Грінченка.

У статті розглянуто форми реалізації проблеми самотності як вияву суперечливого буття людини в поезії та малій прозі Б. Д. Грінченка. Авторами акцентовано на засобах відображення психологічних станів персонажів, що перебувають у стані психологічного афекту.

Ключові слова: проза, поезія, проблема самотності, психологічний афект.

Коломиец Н. Е., Яременко Н. В. Проблема внутренней и социальной изолированности личности в творческом наследии Б. Д. Гринченка.

В статье рассмотрены формы реализации проблемы одиночества как проявления противоречивого бытия человека в поэзии и малой прозе Б. Д. Гринченко. Авторы акцентировали на способах отображения психологических состояний персонажей, которые пребывают в состоянии психологического аффекта.

Ключевые слова: проза, поэзия, проблема одиночества, психологический аффект.

Kolomiyets N. E., Yaremenko N. B. A problem of inner and social isolation of the individual in B. D. Grinchenko's literary heritage.

The article deals with the forms of solitude problem realization as a manifestation of human being contradiction in B. D. Grinchenko's prose and poetry. The authors emphasize the ways of depiction of characters at state of psychological affectation.

Key words: prose, poetry, solitude problem, psychological affectation.

Б. Д. Грінченко в художніх творах неодноразово звертався до осмислення феномену самотності як вияву суперечливого буття людини. Автору вдалося розкрити соціальну ситуацію та суспільні фактори, які 
формують кризу самоідентичності та сприяють появі у людини почуття душевної дисгармонії, пригнічення, а відтак є причиною переживання стану самотності. Поетичні твори Б. Грінченка підтверджують думку Б. Сучкова, який, аналізуючи мистецтво другої половини XIX століття, зазначав, що «зростання відмежованості індивіда від суспільства, пов'язане 3 підсиленням процесу відчуження, надавало своєрідного забарвлення духовному життю кінця ХІХ століття» [6, с. 190].

Позитивний образ передової людини своєї епохи, яка у своїй самотності відділилася від ворожої ій дійсності постає в поезії «Я сам собі у городі гучному». Це людина страждаюча, сповнена драматичних переживань, але разом з тим не позбавлена могутньої волі і прагнення заради загального добра зважитися на самопожертву:

Я сам собі у городі гучному,

Навкруг усе біжить і метушиться, А я сиджу в куточку мовчазному,

Моє життя - самотня тиха праця [2, с.115].

Внутрішній емоційний стан ліричного героя, його відчуженість від мешканців міста передається у творі за допомогою прямих і переносних виражально-зображальних засобів. Пряме називання почуття в першому рядку поезії створює навкруг себе емоційне поле трагічної громадянської самотності. А зовнішні обставини, що породили цю самотність, передано метафоричним висловлюванням: «Навкруг усе біжить і метушиться». Але у творі йдеться не про життєву, побутову самотність ліричного героя, а про відірваність передових людей епохи один від одного і від народу загалом. Поет відтворює душевний стан людини, що відчуває себе під владою самоти, відчуження і віддалення від людей, усвідомлює загальну соціальну байдужість. Безперечно, відчуття недосконалості світу, невідповідності ідеалів людей власним ідеалам ліричного героя відіграє тут значну роль у передачі його психічного стану, викликаного соціальною дійсністю.

Деякі поезії митця порушують проблеми недовговічності, безцільності людського буття, вічного плину живої природи, драматизму земного життя особистості та смерті («Дуб», «Південь на степу», «Тільки одна не пишалась...», «Природо-мати!...», «Хвиля за хвилею плеще й зникає...», «Квітки», цикли «Смерть», «Навіщо?» та інші). Їх мотиви певною мірою трансформують думку про абсурдність життя, чим дещо перегукуються 3 творчістю поетів-експресіоністів кінця XIX - початку XX ст. Так, у поезії «Квітки» відчуття 
нестабільності, дисгармонії посилюється контрастом між квітучою природою та їі неминучою смертю:

Ростуть, живуть, радіють і иявітуть -

І вмруть вони, і вмруть, $і$ зогниють,

Робак гидкий гнилизну поглине,

Не буде пахошів, краси не буде,

А буде смерть, гнилятина й гидота-

I не з самих квіток, ні, не з самих, -

3 усього! Смерть обніме тут усе:

Оиі мої істоти дорогї-

Моя дружина та моя дочка-

I я, і всі, кого люблю, чи бачу, -

Всі зробимось гнилизною, й робак

Нас поглине в своє гидкеє тіло,

I нажереться він $і$ здохне сам!.. [2, с. 95].

Поетичні рядки сповнені драматизму від усвідомлення тлінності всього земного, згасання та перетворення живого в мертве. Драматичне нагнітання створюється словами: «Гнилизну», «зогниють», «вмруть», «робак гидкий», «смерть», «Гнилятина», «Гидота», «Гидкеє тіло», «здохне». У поетичному творі образ смерті подано метафоризовано: «смерть обніме тут усе». Смерть у сприйнятті ліричного героя є наочним проявом залежності людини від дії природних сил. Цю думку підтверджує ряд слів на позначення відчуття облудності, оманливості людського життя: «брехня, облуда та омана»; «глузування з людської душі» [2, с. 95]. Повтори « не з самих квіток, ні, не з самих»; «3 усього! Смерть обніме тут усе»; «і всі, кого люблю, чи бачу, - Всі зробимось гнилизною» підсилюють враження гнітючого стану ліричного героя, його розчарування скороминучістю життя, відчуття трагізму від усвідомлення смертності усього живого, рідного, прекрасного, високодуховного. Усвідомлення невідворотності смерті в поезіях Грінченка не містить відкритого соціального змісту. Образ смерті в його ліриці існує як «певний елемент людської екзистенції, привід для терпіння і страху людського, а також як велика таємниця» [4, с. 434]. У цьому творі особливо яскраво відбилась своєрідна синкретичність творчого методу митця, переплетіння в ньому реалістичних та експресіоністичних рис. Подібне твердження констатує і О. В. Гонюк, вказуючи, що в українській літературі кінця XIX - початку XX ст. художні течії та напрями співіснували, взаємопереплітались [1, с. 11].

(ㄱ Н. Є. Коломієць, Н. В. Яременко, 2012. - 190 - 
Слід зазначити, що в деяких оповіданнях письменника («Сама, зовсім сама», «Батько та дочка», «Дзвоник», «Панько» та інших) відчуття самотності, внутрішнього дискомфорту, душевних затьмарень $\epsilon$ наслідками руйнівних тенденцій жорстокого впливу індустріального міста. Мотиви відокремленості, психологічної ізоляції, смерті тісно перегукуються 3 провідними тенденціями експресіонізму, де вони набувають крайньої екзальтації. Важливо відзначити, що в трагічні моменти життя персонажі творів «Сама, зовсім сама», «Сестриця Галя», «Батько та дочка» та інших звертаються до вищої сили - Бога. За допомогою такого прийому письменник досягає точнішого відтворення душевних переживань, сподівань героїв. У звертаннях до споконвічних, позачасових образів виявляється певна подібність творів письменника до експресіоністської концепції людської загубленості. Адже, як наголошував П. В. Рихло, «богошукання експресіоністів, які намагалися знайти моральну опору i надійне сховище від життєвих невдач у трансцендентальній силі, <..> великою мірою пояснювалися прагненням подолати паралізуюче почуття самотності» [5, с. 173]. Однак в оповіданнях Б. Грінченка, на відміну від експресіоністів, трагічні ситуації не можна сприймати як безповоротні. Вони можуть бути подолані, оскільки є наслідками нездорового суспільного устрою, а не внутрішньої психологічної деформації особистості.

У художньому світі оповідання «Каторжна» домінує відчуття психологічної замкненості, відчуженості, озлобленості на родину й оточення, 3 одного боку, і антигуманність, немилосердя, байдужість, підступність і навіть агресивність, з іншого. Автор цим наштовхує на думку про нездорову атмосферу людського співжиття взагалі. Переживання особистості - жертви людської байдужості і зневаги виражені в останньому передсмертному питанні дівчини та авторському коментарі до нього: «За що? Господи, боже мій! За що? підвелася i, скрикнувши, впала знову на подушку. За кілька хвилин вона була мертва. Її поховано, і ніхто не пожалів іiі. Вона всім осталась каторжною. Санька тільки плакала. I ніхто й не думав одмовити собі на те питання, що вона кинула вмираючи: за що? За що стільки муки, горя та сліз додають людям люди, коли й так життя таке коротке і таке сумне?..» [2, с. 343]. Авторський коментар своєрідно застерігає людей від жорстокості, ненависті, глибше розкриває соціальні мотиви виснажливого розладу особистості 3 людьми, що іiі оточують, i 
наштовхує на думку, що тільки духовна єдність, милосердя, гуманність врятують людство від морального та фізичного апокаліпсису.

Через все оповідання «Сама, зовсім сама» проходить образ міста, який підсилює почуття самотності дівчини, органічно пов'язується 3 іiі душевними переживаннями. Письменник у всьому творі поряд із словом «місто» вживає епітети в «чужому великому місті», «велике місто» [2, с. 264], які підкреслюють процес відчуження особистості від загальної маси людей. Дівчині місто здається ворожим: «Надворі йшов дощ, хоч $і$ невеликий - мов крізь сито сіяв. Але все небо облягло сірими хмарами і віщувало його надовго. На небі ані смужки ясної - скрізь простяглася сіра запона і ні в одному місці не розгорталася. Було холодно, і туман закривав мало не все, що можна бачити, тільки передні будинки ледве визначалися серед його хвиль. Усе велике місто здавалося безкраїм болотом... Вона не дивилася навкруги, не хотіла бачити цих величезних будинків - вони мов гнітили іiі, холодом од їх віяло на неї, бо вона зросла серед сільських привітних, хоч і вбогих, хаток» [2, с. 264]. Використання таких художніх засобів, як: повтори («сірими» - «сіра»; «холодно» «холодом»; «велике» - «величезних»), порівняння («йшов дощ, мов крізь сито сіяв»; «місто здавалося безкраїм болотом»), метафори («небо віщувало його надовго»; «будинки... мов гнітили іiі, холодом од їх віяло»), епітети з психологічно негативною тональністю («сірими»; «холодно») та зорові епітети на означення великих за розміром предметів («велике», «величезних», «безкраїм») увиразнює емоційно-психологічне сприйняття міста персонажем-«маленькою людиною». Урбаністичний пейзаж у творі художньо передає могутню силу міста, яке володарює над долями людей. Слід зазначити, що саме так сприймалося місто письменникамиекспресіоністами. «Концепція філософського осмислення феномену міста як осереддя згубної цивілізації, де все вороже людині, тому що веде ii до моральної деградації й загибелі, - це загальне місце в естетиці експресіонізму, яке однаково стосується як поетичного, так і образотворчого мистецтва цього напрямку» [5, с. 168-169], - писав П. В. Рихло. Спільність урбаністичних пейзажів певною мірою наближає оповідання Б. Грінченка до творів експресіоністів. Проте 3 цього не можна робити висновок про абсолютизацію письменником міста як тотального явища. Місто в оповіданнях письменника - це простір, у якому живе людина. Це місто не набуває самодостатнього значення, не стає загрожуючою силою. За допомогою урбаністичних пейзажів, пропущених крізь призму сприйняття персонажів, письменник

(ㄱ Н. Є. Коломієць, Н. В. Яременко, 2012. - 192 - 
конкретизує свою соціально-політичну ідею, світоглядну позицію, чого не вистачало експресіоністам.

Осіння пейзажна зарисовка в оповіданні «Сама, зовсім сама», що передує сцені самогубства, $є$ своєрідним знаком внутрішнього стану героїні. За своїми внутрішніми художніми якостями вона, як і спогади про таку ж осінь 3 дитинства, замінює розгорнуте відображення складних психічних станів дівчини в їх динаміці. Трагізм ситуації, що наблизила два полярно протилежні стани: життя та смерть, робить сприйняття природи 3 iї багатством та різноманітністю проявів особливо загостреним: «Це саме восени й було. Вона одна-однісінька йшла густим лісом, ішла без стежки, навмання, а золоте листя падало й шелестіло, як і тепер шелестить. I так, як тепер, вона йшла шукати іншого, небесного життя, так і там вона шукала неба, хоч їй і не хотілося тоді вмирати. Але мати їй часто розказувала про рай, про те, що на землі горе, а на небі довічне щастя, - і шестилітній дівчинці схотілося на небо. I вона пішла туди, де небо торкається до землі, - там мусили бути східці на небо, і це було за лісом» [2, с. 273]. Цей пейзаж передає не лише красу природи, а й наповнюється символіко-філософським змістом. Самогубство героїні постає як вияв протесту проти жорстокої дійсності. Розв'язка оповідання трагічна. Смерть Марина сприймає як порятунок від тягаря життєвих проблем у антигуманному суспільстві. Смерть героїні ставить усі крапки над «і», загострюючи соціальне спрямування твору. У цьому оповіданні особливо відчутне імпресіоністичне начало в творчій манері письменника.

Час і простір оповідань Б. Грінченка мають як конкретне, так i символічне значення. Так, на початку оповідання «Сама, зовсім сама» дія відбувається в замкненому просторі - у кімнаті, де раніше померла мати головної героїні. Відчуття замкненості відіграє значну роль у передачі психічного стану Марини. Дійсність сприймається у зв'язку із замкненим простором. В оповіданні ми знаходимо й перехід у протилежний вимір простору - потойбічний світ. Автор змальовує широкі, безкраї простори, 3 яких і землі не видно. I раптом повернення до гіркої дійсності, де на противагу безкрайому, одвічному простору знову постають чорні стіни, чорна задимлена стеля. Отже, оповідання побудоване на контрасті локального та глобального просторів. Таке поєднання активізує читацьку уяву, впливає на неї, поглиблюючи драматизм сприйняття. 
На основі проведеної роботи можна стверджувати, що зображення персонажів у стані психологічного афекту постає як стильова домінанта, в основу якої автор поклав принцип психологізму в зображенні людської особистості. Для творчості Б. Грінченка властиве відображення найхарактерніших суспільних суперечностей доби, прагнення відтворити душевний світ своїх персонажів, їх переживань, спричинених дійсністю. Порушуючи проблему самотності особистості, автор прагнув позначити для індивіда шляхи виходу 3 духовної антропологічної кризи через віднайдення внутрішньої опори для ствердження власної самоідентичності.

\section{Література}

1. Гонюк О. В. Поетика малої прози Осипа Маковея : автореф. дис. ... канд. філол. наук спец. 10.01.01 «Історія української літератури» / О.В.Гонюк ; Дніпропетровський державний університет. - Дніпропетровськ, 1997. - 17 с.

2. Грінченко Б. Д. Твори : у 2-х т. / Б. Д. Грінченко. - К. : Вид-во АН УРСР, 1963. - T. $1 .-603 \mathrm{c}$.

3. Грінченко Б. Д. Твори : у 2-х т. / Б. Д. Грінченко. - К. : Наукова думка, 1990. T. $1 .-640 \mathrm{c}$.

4. Drabarek Barbara, Falkowski Jasek, Rowinska Izabella. Slownik motiwow literackich. - Warszawa, 1998. - S. 434 (Цит. за: Ткачук М. П. Українська поезія останньої третини XIX століття : основні тенденції розвитку й естетична стратегія : [навч. посібник] / М. П. Ткачук. - Тернопіль : ТДПУ, 1998. - С. 64).

5. Рихло П. В. Освоєння поетики $\mathrm{i}$ художніх принципів німецького експресіонізму в ліриці Стефана Гермліна / П. В. Рихло // Поетика. - К. : Наукова думка, 1992. - С. 167-183.

6. Сучков Б. Исторические судьбы реализма. Размышления о творческом методе / Б. Сучков. - М. : Советский писатель, 1973. -504 с.

Стаття надійшла до редакції 22.10.2012 p. 